\title{
Public Policy Implementation in Efforts to Improve Public Service Quality in Tangerang City
}

\author{
Syamsul Bahri ${ }^{1}$, Khasan Effendy ${ }^{2}$, Ngadisah ${ }^{3}$, Sampara Lukman $^{4}$ \\ 1,2,3,4 Institut Pemerintahan Dalam Negeri (IPDN), Indonesia \\ Email: syamsulb1973@gmail.com
}

\begin{abstract}
Public service is the most critical task for the Tangerang City government bureaucracy. The Tangerang City Government is the government organ closest to the people it serves to empower. This study seeks to describe the implementation of public policies to improve the quality of public services to improve people's welfare in the city of Tangerang. This research uses a qualitative approach with descriptive methods. The results show that public services to improve welfare can be seen from 5 dimensions, namely: (1) Tangibles are something that is visible and directly proven, generally aimed at the form of office appearance, the comfort of the room where it provides public services, the completeness of the facilities provided, the presence of officers who serve to support implementation of public services; (2) Reliability, which is the ability to deliver promised public services in a timely manner, according to procedures, equality / equal treatment of officers with simplicity, and speed, is a reliable, accurate and consistent capability in providing public services as desired by consumers (3) Responsiveness is a high sensitivity towards consumers followed by acting appropriately in accordance with the needs as seen by the desires of public service providers to help consumers; (4) Assurance as a guarantee of security in obtaining public services so that there are no doubts about the emergence of errors in the provision of public services; (5) Emphaty, namely feeling what other people think and trying to understand and understand what the wants, wants and needs of customers include; understanding customer needs, desires (motivation) to help customers (society), conformity of service to customer needs (community), concern for customers (community), and the desire to follow up on criticism and suggestions with problems managing the needs of service users.
\end{abstract}

Keywords: Public Service, Tangibles, Reliability, Responsiveness, Assurance, Empathy.

\section{A. INTRODUCTION}

Implementation is implementing a policy in which rules and regulations have been planned or decided, which implementation is one of the stages of the policy (Tangkilisan, 2003). Meanwhile, Widodo states that policy implementation is a process that involves several sources, including people, funds, and organizational capabilities carried out by the government and the private sector (individuals or groups) (Widodo, 2007).

In essence, an implementation is a series of planned and gradual activity processes carried out by the implementing agency based on policies that have been established by the authorities (Nigro et al., 2012). When referring to Mazmanian and Sabatier's views as quoted by Wahab (2010), it is said that: implementation is the implementation of fundamental policy decisions, usually in the form of laws but can also take the form of critical executive orders or conclusions". A decision usually 
identifies the problems to be achieved and the various ways to structure the implementation process (Rondinelli \& Cheema, 1983).

Grindle (1980), further argues that "basically the implementation of public policies can be analyzed based on two things, namely the content of policy (the content of policy) and the context of policy (context of implementation)." This view indicates that the success of a policy implementation activity is influenced by content. Policy content is an essential factor in determining the outcome of an implementation initiative. However, in addition to the policy's content, environmental factors (context), including social, political, and economic conditions, also determine the success of the policy implementation (Akib, 2012).

After the policy is implemented on a group of policy objects, both the community and organizational units, it will cause various impacts resulting from the policy in question (Hamdi, 2014). This is, as stated by Islamy (2003) that, "every policy that has been made and implemented will have a certain impact on the target group, both positive (intended) and negative (unintended)". For this reason, a review of policy effectiveness and achieving the goal of minimizing dissatisfaction from all stakeholders means that deviations from the policy are not too far and undoubtedly prevent obstacles in the implementation of policies in the future (Dunn, 2013).

In simple terms, Lewis and Booms (1980) define service quality as "a measure of how well the level of service provided is following customer expectations." Based on this definition, the quality of public services is determined by institutions' ability to meet the needs and desires of society following community expectations (Tjiptono, 2008).

In connection with the quality of public services carried out by public organizations, Lukman (2000), states that "the quality of public sector services is a service that satisfies the community following service standards and public service principles". In short, Tjiptono (1996), provides an understanding of service quality as "the level of excellence expected and control over that level of excellence to meet customer desires".

Quality public services are expected to provide benefits for the people who receive services and organizations or governments that provide services (Robbins, 2016). In this regard, Rasyid (1997) states the benefits obtained from the optimization of effective and fair services "can directly stimulate the birth of public respect for bureaucrats' professional attitude as servant leaders. At a certain level, the presence of bureaucrats who sincerely serve the community will encourage the maintenance of a hard-working, disciplined, and competitive climate".

Public demand for the quality of public services is increasing day by day; this is under the new paradigm in government management. By the concept of Banishing Bureaucracy, The Five Strategies for Reinventing Government by Osborne and Plastrik (1997), that refers to the principle of organizational reform, the government apparatus is more efficient and effective in anticipating the demands of development reform so that the expertise and skills they have are fully utilized for the benefit of 
many people (the public) with the concept of service-oriented to community decisions (customer satisfaction) (Gaebler, 1993).

The best way for any provider of quality public service services is to use a combination of several quality perspectives and to actively adapt them at any time to the conditions at hand. Berry et al. (1988) define the quality of public services as an opinion or attitude relative to the quality of public services and the results of comparing expectations with customer perceptions of the quality of public services received.

Berry et al. (1988: 19-20) illustrate the quality of public service as a journey. In that, there is an arch that gets profit growth consisting of cost savings and differentiation. To achieve this, it is pursued by implementing quality public services. Cultivating the quality of public services is not as easy as turning your palms because many government agencies are not responsive in their implementation. The fault lies in each government agency or institution's orientation, which still considers the quality of public services as a goal, not as a continuous process, meaning that it is continuously pushed towards improvement.

\section{B. METHOD}

The research design used in this research is descriptive analysis design with a qualitative approach. Locke, Spriduso, and Silverman (in Creswell, 1994) argued that "qualitative research is interpretative research. As such, the researchers' biases, values, and judgment become stated explicitly in the research report. Such openness is considered useful and positive". The same thing, Moleong (2008) says that "qualitative research methods are research procedures that produce descriptive data in the form of written or spoken words from people and observed behavior. Qualitative research requires guidance in the formulation of substantive theories based on data.

Overall, the research results are analyzed in-depth descriptions to understand the meaning and understand factually (verstehen) of the real empirical conditions with various observed variations of the research object. The research results obtained through realistic portraits are closer to relevant theories for interpretation to determine the degree of factual development of the research object. It is known that the limits of the theoretical ability to explain the evolution of existing empirical facts and the limitations of existing points in meeting existing academic standards (Bungun, 2008).

\section{RESULT AND DISCUSSION}

Given the importance of public services in improving community welfare in management, it is essential to determine the efficiency and effectiveness of the Tangerang City government's administration, various legislative products issued after the reform since 1998. Concerning the government of Tangerang City, it is managed effectively and efficiently if there is a healthy and robust bureaucracy, namely; a bureaucracy that is professional, neutral, open, democratic, independent, 
and has integrity and competence in carrying out its duties and responsibilities as public servants and state servants, in carrying out the mission of the nation's struggle to realize the ideals and goals of a state

Public services to improve welfare is the most critical tasks for the Tangerang City government. Tangerang City Government is the government organ closest to the community it serves to implement. The study and implementation of public services to improve people's welfare cannot merely be left to the private sector. However, there is a strong tendency that the government's role has begun to diminish and acts more as a facilitator and dynamist. Activities and forms of public services to improve welfare because of their nature and types cannot be handed over or taken over by the private sector; the government still takes a more significant and determining role. Meanwhile, in other activities, such as health education, housing, and agriculture, the private sector plays a more substantial role.

Productivity in the public service sector improves community welfare to the extent that these results are achieved with the desired standards given to the community. Due to government, structural design is not for effectiveness and efficiency, but also (social) justice. Even the element of justice is the most important. For example, a service is only called fair if public services to improve the welfare of the community are achieved and enjoyed by everyone who has the right when needed by those concerned. This is related to government science's fundamental principles and values, namely human justice (human justice) public services, to improve public welfare related to government.

Several public service activities to improve society's welfare that is still dominantly managed by the government are generally monopolistic or semimonopolistic. In providing public services to improve welfare based on laws and regulations, be fair, impartial, proportionate, clean, and prioritize many people's interests compared to their interests. Therefore, public services to improve welfare are seen in five dimensions, namely: tangibles, reliability, responsiveness, assurance, and empathy as follows:

\section{Tangibles}

Tangibles are visible and directly evident, generally aimed at the office's appearance, the comfort of the room where it provides public services, the completeness of the facilities provided, the presence of officers serving to support the implementation of public services. This physical appearance is related to physical facilities and infrastructure, such as buildings, office facilities, communication facilities, and personnel's physical appearance. It includes the condition of the surrounding environment prepared by service providers.

The appearance and preparation of the physical facilities of the institution and the condition of the surrounding environment is clear evidence of public services to improve the welfare of the community provided by service providers at educational institutions in elementary, junior, and senior high schools; the overall physical appearance gets attention to the physical appearance of personnel (leaders, advisors academics and employees). This physical appearance can easily be observed that the 
more complete and perfect this physical appearance, the better public services to improve society's welfare include; completeness of facilities and infrastructure, strategic location, comfortable room, adequacy of officers, and cleanliness. In Kota Tangerang, almost all schools have adequate physical buildings. They refused assistance from the center in some cases because all of them had been constructed adequately.

Physical appearance, equipment, personnel, and communication media are not only related to tangible facilities and infrastructure, such as buildings, office facilities, communication facilities, and personnel forms but also include the condition of the surrounding environment prepared by service providers from all of these forms that receive attention, especially -more the form of personnel (leaders, academic advisors, and employees). Tangibles are easily observed to be more complete and perfect, so it is seen as getting better in Tangerang City that almost all public services have buildings, office facilities, communication facilities as well as the appearance of personnel but also include the condition of the surrounding environment that is not fully prepared by service providers. Both have; completeness of facilities and infrastructure, strategic location, room comfort, adequacy of officers, and cleanliness. This is due to physical appearance, equipment, personnel, and communication media that improve public services to the community, always focusing on achieving public services so that the public services provided meet customers' desires or society.

Conditions are more influenced by the tangibles of the target group to serve the community and create conditions that allow each organization to develop their abilities and creativity to achieve common goals in carrying out their duties in Tangerang City public services have tangibles where the community knows and participates in proposing public services, namely; completeness of facilities and infrastructure, strategic location, comfortable room, adequacy of officers, and cleanliness. One of the implications of tangible is that they are always progressing towards progress in various matters relating to community affairs. The government is no longer positioned as everything in the decision-making process, but it involves the community. Community involvement in the decision-making process is possible when tangibles regarding various activities of public service affairs to the community are carried out.

In general, describing public services in Tangerang City from the perspective of tangibles in the formation of the target group has been carried out properly in the sense that it has paid attention to the accuracy in determining who has the right to become an adequate group, someone can't understand the problems at hand. Given the limitations, in this case, the level of public services is still relatively low, so that the formation of community group members is left to the community with the guidance of Tangerang City public services and other implementing officers, it is not surprising that the formation of target groups is following the good wishes of the community. Completeness of facilities and infrastructure, strategic location, room comfort, staff adequacy, and cleanliness have not been running optimally. The target 
group's tangibles influence these conditions in building infrastructure and facilities, both physical and social, and institutional development in Tangerang City accordingly. With the desires and goals of the community who have the authority on certain parties to carry out their duties and possible.

2. Reliability

Reliability is the ability to provide promised public services promptly. According to procedures, equality / equal treatment of officers, simplicity, and speed are reliable, accurate, and consistent in delivering public services as desired by consumers. Reliability shows that public service is due to the ability to carry out the promised services appropriately and reliably, which can improve public services to the community, always focuses on the achievement of public services so that the public services provided are expected to meet the wishes of customers or society.

The suitability between public services and service users' expectations is a determining factor for public service reliability in Tangerang City. It has succeeded in implementing it on time, according to procedures, equality / equal treatment of officers, simplicity, and speed following the region's conditions and potential, so it is used effectively, namely close to customers/consumers. This means not a delegation of tasks but also a delegation of decision-making processes and full responsibility for the ability to carry out the promised services. Because reliability is seen as an opportunity for a system or product to work following the function up to a specific period to calculate correctly. Applying reliability in the principle of preparing public services as best as possible is done to produce optimal performance, so that public services increase, where the important thing is the reliability to be implemented is the ability to form public services that are promised appropriately and have a sense of service responsibility public to society. In addition to realizing the reliability of public services includes, on time, according to procedures, equality / equal treatment of officers, simplicity, and speed on an ongoing basis. This means expediting public service activities aimed at creating services to the community.

The continuity of reliability, especially those related to public services, is essential as a manifestation and involvement of the community in determining their destiny. So far, the reliability associated with public services is often neglected. In comparison, reliability is essentially his responsibility to society, including, on time, according to procedures, equality / equal treatment of officers, simplicity, and speed. The public has the right to obtain the broadest possible information without exception. It is time for the community to make decisions related to public service issues in Tangerang City.

Public services in Tangerang City from the point of reliability in the formation of target groups have been appropriately implemented because they have paid attention to the accuracy in determining who has the right to become an adequate group. Given the relatively low limitations of public services, community group members' formation is left to the community in Tangerang City and other implementing officers; it is not surprising that the formation of target groups is following the good wishes of the community. This condition is more influenced by 
the state of reliability of the target group in Tangerang City following the community's desires and goals, where the government has the authority to carry out specific tasks as well as possible.

\section{Responsiveness}

Responsiveness is a high sensitivity to consumers, followed by acting appropriately according to the needs seen by public service providers' desire to help consumers. The responsiveness referred to here is the willingness and speed of service providers to provide public services to service users, including; responsiveness to customer needs, acceptance of critical and customer suggestions, attention, easy, and have adequate knowledge, reflected in the willingness of institutional leaders and administrative staff to respond quickly to complaints and community needs so that service is fast or the responsiveness of institutional managers is often her dream.

Regarding responsiveness shows that the form of public service is not yet thoroughly good. This is due to fast service or responsiveness that improves public services to the community, always focusing on the achievement of public services including; responsiveness to customer needs, acceptance of critical and customer suggestions, attentive, accessible, and have sufficient knowledge so that public services provided to the community are expected to meet customer desires. Implementing responsiveness in the principle of preparing public services as best as possible is done to produce optimal performance, so that public services increase, where the important thing is responsiveness to be implemented is fast service or responsiveness that is implemented appropriately and has a sense of responsibility on public services to the community.

Regarding responsiveness by showing public services is not yet entirely satisfactory. This means that responsiveness in public services is more influenced by the target group's responsiveness to serve the community and creates conditions that allow each community to develop services quickly or responsiveness to achieve common goals in carrying out local government duties and functions in Tangerang City. Public service activities have responsiveness where the public knows and participates in proposing public service programs.

One of the implications of responsiveness is that it is always in progress towards progress in various matters relating to community affairs. The government is no longer in a position as everything in the decision-making process, but it involves the community. Community involvement in the decision-making process is possible when the responsiveness process is carried out regarding various public service affairs activities.

Public services in Tangerang City from the perspective of responsiveness in the formation of target groups have been carried out properly in the sense that they have paid attention to the accuracy in determining who has the right to become an adequate group; someone can't understand the problems faced in particular; responsiveness to customer needs, acceptance of critical and customer suggestions, attentive, accessible, and have adequate knowledge. Given the limitations, in this 
case, the level of public services is still relatively low, so that the formation of community group members is left to the community with Tangerang City public services and other implementing officers, it is not surprising that the formation of target groups is following the good wishes of the community. Responsiveness high sensitivity to consumers followed by acting appropriately as needed. Responsiveness also sees the desire of public service providers to help their consumers. The responsiveness referred to here is the willingness and speed of service providers to provide public services to service users.

\section{Assurance}

Assurance is a guarantee of security in getting public services so that there is no doubt about the emergence of errors in public services provision. To provide service users to service providers is manifested through institutional managers' skills in delivering public services from managers in providing information to the public as service users. The open nature of institutional managers guarantees and public confidence in the seriousness of managers in delivering public services including; security, legal certainty if you get a loss due to service, trust, responsibility, and clarity of service instructions are special programs in Tangerang City manifested through the belief of institutional managers in providing public services that are polite and open from managers in providing information to the public as service users.

Applying assurance in principle to prepare the quality of public services as best as possible is done to produce optimal performance. Public services are increasing, where assurance to be carried out is the ability to form the promised services appropriately and have a sense of responsibility for public services to the community. In addition to realizing public service assurance includes security, legal certainty if you get a loss due to service, trust, responsibility, and clarity of public service instructions in a sustainable manner. This means expediting public service activities aimed at creating public services to the community. In turn, to accelerate government functioning in Tangerang City with the belief that drives the motivation to achieve success.

A state of assurance for the target group to serve the community and create conditions that allow each community to develop abilities and creativity to achieve common goals in carrying out thinking and behaving, responding to change, facing competition, forming customer loyalty, and building strategies in Tangerang City.

The formation of the target group has been carried out properly because it has paid attention to the accuracy in determining who has the right to become an adequate group; the community can't understand the problems at hand. Given the limitations, in this case, the level of public services is still relatively low, so that the formation of community group members is left to the community in Tangerang City and other implementing officers, it is not surprising that the formation of target groups following the good wishes of the community includes security, legal certainty if they get losses due to service, trust, responsibility, and clarity of service instructions have not been running optimally. The state of assurance of the target 
group in public services in Tangerang City is following the belief that contains certainty as a form of support for government officials with an imagination which aims from the public who have the authority to carry out tasks frequently (repetitive) and create a deep impression nicely.

\section{Empathy}

Empathy feels what other people think and strives to understand and understand what customer wants, wants, and needs include; understanding customer needs, desire (motivation) to help customers (community), conformity of service to customer needs (community), concern for customers (community), and the desire to follow up on criticism and suggestions with problems with the management of the needs of service users.

The higher the manager's understanding of the problems faced by public services as service users, the better the public service. In various institutions engaged in services, empathy is often considered the most important because it directly touches public services from the personal side of service users. For the convenience of public services to entrepreneurs, the Tangerang City Government always fully engages the Tangerang City Regional Representative Council to ensure the smooth fulfillment of regulating, development, empowerment, and public service plans with the realities of the field as well as predicting the amount of budget needed to implement the program. In this case, it is easier to expedite the considered credible needs and become a faster, more precise, and meaningful facilitator.

It looks not easy to observe but is felt by service users. The higher the understanding of customer needs, desire (motivation) to help customers (community), conformity of service to customer needs (community), concern for customers (community), and the desire to follow up on criticism and suggestions of problems faced by the community as service users, the quality of service the public is getting better. In various institutions in Tangerang City that are engaged in services, this empathy is often the most important because it directly touches public services from the side of service users who are required to care, pay attention to customers to help, and facilitate public service activities needed by the community to try and efforts to achieve success.

Public service improvement is measured by government performance, the extent to which the bureaucracy carries out public service management's operationalization. Public trust depends on individual bureaucrats to carry out activities so that public services are felt and enjoyed by the community. The level of public satisfaction as service users is determined by government actors who provide quality public services with a sincere heart. The government bureaucracy has an Integrated Licensing Service Agency regulating public services' smooth-running through stakeholders, or tripartite cooperation between the government, entrepreneurs, and the community. The government has an easier task, which only has to direct, lead. Then the people are taboo on what to do for their welfare and create a government that is effective and prioritizes the interests of the people of Tangerang City and the Indonesian people in general. 
To realize empathy, public service includes understanding customer needs, desire (motivation) to help customers (society), conformity of service to customer needs (community), concern for customers (community), and the desire to follow up on criticism and suggestions continuously. This means developing effective public services, which is one of the empathy that is needed in the context of selfdevelopment, both personally and professionally. Therefore the ability to do empathy (compassion) is quite useful in Tangerang City. It is not surprising that the formation of the target group follows the community's wishes with openness and trust in building cooperation or synergy with the community in Tangerang City. A sense of empathy (empathy) enables one to convey a message (message) in a way and attitude that makes it easier for the recipient of the message (receiver) to receive it. Understanding empathy with the needs, wants interests, hopes, and pleasures of society.

\section{CONCLUSION}

Efforts made to implement Tangerang City public policies in realizing the quality of public services are still lacking awareness of public participation by prioritizing compliance with applicable systems and regulations; for this, an automatic system can be developed with optimal use of information and communication technology, namely by developing Network systems that use information and communication technology via the internet, online and digitally with the activities carried out are still not effective in improving people's welfare.

The findings in this study are: the implementation of the smart city policy of Tangerang City in realizing the quality of public services to fulfill the trust in society in a wise orderly manner by a feedback system that provides information and communication technology via the internet, online and digital about the reality in the field which is done in a transactional manner as a material for consideration of making effective government program rules to support the stability of the implementation of development activities, empowerment, and services as a whole.

\section{REFERENCES}

1. Akib, H. (2012). Implementasi kebijakan: Apa, mengapa dan bagaimana. Jurnal Ilmiah Ilmu Administrasi Publik, 1(1), 1-11.

2. Berry, L. L., Parasuraman, A., \& Zeithaml, V. A. (1988). The Service-Quality Puzzle. Business Horizons, 31(5), 35-43.

3. Bungin, M. B. (2008). Penelitian Kualitatif. Jakarta: Kencana Prenada Media Group.

4. Cafezio \& Morehouse, P. D. (1998). Secret of Break Through Leadership. Mumbai: Jaico Publishing House.

5. Creswel, J. W. (1994). Research Design Qualitative E Quantitative Approaches.New Delhi: Sage Publications.

6. Dunn, W. (2013). Pengantar Analisis Kebijakan Publik. Yogyakarta: Gadjah Mada University Press. 
7. Gaebler, T. (1993). Reinventing Government: How the Entrepreneurial Spirit is Transforming the Public Sector. Plume.

8. Grindle, M. S. (1980). Policy Content and Context in Implementation. Politics and policy implementation in the Third World, 3-34.

9. Hamdi, M. (2014). Kebijakan Publik: Proses, Analisis, dan Partisipasi. Ghalia Indonesia.

10. Irfan, I. M. (2003). Prinsip-Prinsip Perumusan Kebijaksanaan Negara. Jakarta: Bumi Aksara.

11. Lewis, R. C., \& Booms, B. H. (1983). The Marketing Aspects of Service Quality. Emerging Perspectives on Services Marketing, 65(4), 99-107.

12. Lukman, S. (1999). Manajemen Kualitas Pelayanan. Jakarta: STIA-LAN Press.

13. Moleong, L. J. (2008). Metodologi Penelitian Kualitatif. Bandung: Remaja Rosda Karya.

14. Nigro, L. G., Nigro, F. A., \& Kellough, J. E. (2012). The New Public Personnel Administration. Cengage Learning.

15. Osborne, D., \& Plastrik, P. (2000). Memangkas Birokrasi: Lima Strategi Menuju Pemerintahan Wirausaha. Jakarta: PPM.

16. Rasyid, R. (2004). Desentralisasi dalam Rangka Menunjang Pembangunan Daerah. Jakarta: LP3ES.

17. Robbins, S. P. (1990). Organizational Behavior: Concepts and Controversies. New Jersey: Prentice Hall. Inc.

18. Rondinelli, D. A., \& Cheema, G. S. (Eds.). (1983). Decentralization and Development: Policy Implementation in Developing Countries (p. 100). Beverly Hills: Sage.

19. Sabatier, P., \& Mazmanian, D. (1980). The Implementation of Public Policy: A Framework of Analysis. Policy Studies Journal, 8(4), 538-560.

20. Tangkilisan, H. N. (2003). Implementasi Kebijakan Publik. Yogyakarta: Lukman Offset YPAPI.

21. Tjiptono, F. (1996). Manajemen Jasa. Yogyakarta: Andi

22. Tjiptono, F. (2008). Service Management Mewujudkan Layanan Prima. Yogyakarta: Andi.

23. Wahab. (1991). Analisis Kebijaksanaan: dari Formulasi ke Implementasi Kebijaksanaan Negara. Bumi Aksara.

24. Widodo, J. ( 2007). Membangun Birokrasi Berbasis Kinerja. Malang: Bayumedia. 